\title{
Konflik Kerja-Keluarga Dalam Kalangan Pensyarah: Satu Tinjauan
}

\author{
Nor Azimah Chew Abdullah*
}

Fakulti Pengurusan Perniagaan, Universiti Utara Malaysia, 06010, Sintok, Kedah, Malaysia

*Corresponding author: norazimah@uum.edu.my

\begin{abstract}
The main objective of this study was to explore the relationships between work-family conflict, job involvement and family involvement among lecturers from the higher education institution in the northern region of Malaysia, who had child under the age of seventeen and below. The sample size was 151 respondents. Respondents were later classified into 97 male lecturers (64.2\%) and 54 female lecturers (35.8\%). Data was collected using questionnaires. Data analysis was done using descriptive statistics, t-test, Pearson correlation and regression. The Pearson correlations showed that job involvement and family involvement were not highly correlated with work-family conflict. The t-test also showed no significant differences between male and female lecturers in work-family conflict. Job involvement and family involvement do not explained the variation in work-family conflict.
\end{abstract}

Keywords: Work-Family Conflict, job involvement, family involvement, dual-career couples

\begin{abstract}
Abstrak
Tujuan kajian ini adalah untuk meninjau hubungan di antara konflik kerja-keluarga dengan penglibatan dalam kerja dan penglibatan dalam keluarga dalam kalangan pensyarah-pensyarah di Institusi Pengajian Tinggi di utata Semenanjung Malaysia dan tumpuan kajian adalah terhadap pasangan dwi-kerjaya yang mempunyai anak berumur 17 tahun dan ke bawah. Saiz sampel adalah seramai 151 orang responden. Responden telah dikategorikan kepada 97 orang pensyarah lelaki (64.2\%) dan 54 orang pensyarah perempuan (35.8\%). Data telah dikutip melalui borang soal-selidik. Kaedah statistik deskriptif, ujian-t, korelasi Pearson dan analisis regresi telah digunakan untuk menganalisis data. Ujian korelasi Pearson menunjukkan bahawa wujud hubungan yang tidak signifikan di antara penglibatan dalam kerja dan penglibatan dalam keluarga dengan konflik kerja-keluarga. Ujian-t juga menunjukkan bahawa tiada perbezaan yang signifikan dalam konflik kerja-keluarga dalam kalangan pensyarah lelaki dan wanita. Dapatan kajian juga menemui penglibatan dalam kerja dan penglibatan dalam keluarga tidak menerangkan perubahan dalam konflik kerja-keluarga.
\end{abstract}

Kata kunci: Konflik kerja-keluarga, penglibatan dalam kerja, penglibatan dalam keluarga, pasangan dwi-kerjaya

(C) 2016 Penerbit UTM Press. All rights reserved

\subsection{PENDAHULUAN}

Era millenium menampakkan perubahan tren tenaga buruh yang telah berganjak ke arah dwi-pendapatan dan tidak lagi berciri tradisi. Macewen dan Barling (1988) menyokong pernyataan ini dengan menyatakan bahawa institusi keluarga hari ini tidak lagi berciri tradisi di mana hanya bapa sahaja yang keluar bekerja dan ibu menguruskan rumah tangga tetapi kini kebanyakan isteri juga turut mencari nafkah. Karambayya dan Reilly (1992) menguatkan lagi teori ini dengan menekankan bahawa keluarga dwi-kerjaya telah wujud apabila bilangan wanita sebagai tenaga kerja telah meningkat. Kini lebih ramai wanita terlibat dalam pekerjaan di luar rumah dan lelaki pula turut memainkan peranan dalam keluarga secara aktif (Frone \& Rice, 1987). Senario dwi-kerjaya telah menyebabkan model keluarga tradisi yang menjadi idaman semua semakin sukar untuk dicapai (Covin \& Brush, 1993). Good, Gentry dan Sisler (1990) mendapati bahawa keluarga dwi-kerjaya mudah terdedah dan dipengaruhi oleh konflik kerja-keluarga apabila peranan kerja dan keluarga bergabung. Arah aliran baru ini sedikit sebanyak telah mengubah kehidupan pasangan dwi-kerjaya kerana perlu mengimbangi peranan kerja dan keluarga. Kajian lepas juga menemui perkaitan di antara ketegangan dengan masa dan keperluan tenaga; kekurangan masa luang; keperluan keluarga berbanding keperluan kerja dan konflik peranan (Good et al., 1990). Konflik kerja-keluarga juga turut dikaitkan dengan akibat yang negatif seperti penurunan produktiviti, kehilangan masa kerja, ketidakpuasan kerja, lantik-henti, peningkatan risiko kesihatan, prestasi yang rendah, kepuasan dalam hidup yang rendah dan tekanan (Covin \& Brush, 1993; Greenhaus \& Beutell, 1985). Justeru, kajian ini adalah untuk menilai hubungkait di antara konflik kerja-keluarga dengan penglibatan dalam kerja dan penglibatan dalam keluarga dalam kalangan pensyarah di Institusi Pengajian Tinggi di utara Semenanjung Malaysia dan tumpuan kajian adalah terhadap pasangan dwikerjaya yang mempunyai anak yang berumur 17 tahun dan ke bawah. 
Objektif kajian adalah:

i. Menerangkan hubungan di antara konflik kerja-keluarga dengan penglibatan dalam kerja dan penglibatan dalam keluarga.

ii. Mengenalpasti kewujudan perbezaan konflik kerja-keluarga yang dihadapi oleh pensyarah lelaki dan wanita.

iii. Menentukan pengaruh penglibatan dalam kerja dan penglibatan dalam keluarga terhadap konflik kerja-keluarga.

\subsection{KAJIAN LITERATUR}

\section{Konflik Kerja-Keluarga}

Konflik kerja-keluarga (Adams, King \& King, 1996; Duxbury \& Higgins, 1991; Good, Gentry \& Sisler, 1990; Gutek, Searle \& Klepa, 1991) dikenali juga sebagai konflik antara peranan (Kopelman, Greenhaus \& Connolly, 1983; Macewen \& Barling, 1988) atau konflik kerja-rumah (Bacharach, Bamberger \& Conley, 1991). Schermerhorn, et al. (1991) mendefinisikan konflik kerja-keluarga sebagai konflik antara peranan di mana berlakunya ketidakserasian dalam dua peranan yang dimainkan oleh individu yang sama. Sebagai contoh, bila bebanan tugas bertambah, seseorang individu perlu bekerja lebih masa pada waktu petang dan hujung minggu. Keluarganya merasakan bahawa tanggungjawabnya terhadap mereka diabaikan. Dapatan Greenhaus dan Beutell (1985) mendapati bahawa konflik kerja-keluarga berlaku apabila seseorang individu memainkan pelbagai peranan yang memerlukan masa, tenaga dan komitmen. Good, Gentry dan Sisler (1990) mentakrifkan konflik kerja-keluarga sebagai konflik antara peranan yang sering dihadapi oleh pasangan dwi-kerjaya di mana kekangan masa disebabkan oleh pelbagai keperluan yang perlu dipenuhi oleh setiap pasangan suami-isteri. Menurut mereka lagi, konflik kerja-keluarga wujud apabila individu mengalami kekangan keperluan daripada domain kerja dan keluarga.

Menurut Higgins, Duxbury dan Lee (1994), keperluan kepada pelbagai peranan menghasilkan dua jenis ketegangan iaitu lebihan bebanan dan campurtangan. Lebihan bebanan berlaku apabila keperluan untuk masa dan tenaga adalah terlalu sukar untuk dipenuhi. Kewujudan campurtangan pula berlaku apabila banyak kerja dan aktiviti untuk keluarga perlu dilakukan dalam tempoh masa yang sama tetapi pada lokasi yang berlainan. Higgins et al. (1994) mendapati peranan campurtangan boleh dikategorikan kepada dua komponen iaitu campurtangan keluarga terhadap kerja dan campurtangan kerja terhadap keluarga. Campurtangan keluarga terhadap kerja berlaku apabila tanggungjawab terhadap keluarga menghalang prestasi kerja seperti anak sakit menyebabkan terpaksa mengambil cuti dari kerja (Gutek, Searle \& Klepa, 1991).

Campurtangan kerja terhadap keluarga pula timbul apabila aktiviti kerja menyekat tanggungjawab terhadap keluarga seperti masa yang lama di tempat kerja menghalang ibu atau bapa bersama keluarga di rumah (Gutek, Searle \& Klepa, 1991). Higgins et al. (1994) menyokong cadangan Gutek et al. dengan menyatakan bahawa campurtangan keluarga terhadap kerja dan campurtangan kerja terhadap keluarga adalah berasingan walaupun mempunyai perkaitan dan merupakan komponen kepada konflik kerja-keluarga.

\section{Perbezaan Konflik Kerja-keluarga}

Covin dan Brush (1993) mendapati jantina boleh mempengaruhi gelagat terhadap isu kerja-keluarga. Sebagai contoh, mereka mendapati daripada kajian lepas bahawa wanita lebih tinggi dipengaruhi konflik kerja-keluarga berbanding lelaki kerana wanita melihat isu ini lebih kritikal daripada lelaki. Higgins, Duxbury dan Lee (1994) mendapati jantina boleh mempengaruhi keupayaan untuk mengimbangi kerja dan keluarga dalam pelbagai cara. Menurut pandangan mereka lagi, lebih banyak masa yang ditumpukan terhadap aktiviti kerja maka individu tersebut akan mengalami campurtangan daripada kerja terhadap keluarga. Begitu juga sebaliknya, jika banyak masa diperuntukkan untuk aktiviti keluarga seperti membuat kerja rumah dan menjaga anak maka individu tersebut akan mengalami campurtangan dari keluarga kepada kerja. Terdapat juga perkaitan yang positif di antara jumlah masa yang diagihkan untuk peranan kerja dan keluarga dengan bebanan peranan (Higgins, Duxbury \& Lee, 1994). Ibubapa yang mempunyai anak-anak yang kecil mengalami konflik kerja-keluarga lebih tinggi berbanding ibubapa yang mempunyai anak-anak yang dewasa kerana kehadiran anak-anak berusia 17 tahun dan ke bawah berkait secara positif dengan konflik kerja-keluarga. (Stoner et al., 1990/91)

Daripada kajian lepas, Higgins, Duxbury dan Lee (1994) mendapati bahawa wanita yang bekerja banyak menghabiskan masa untuk aktiviti keluarga dan membuat kerja-kerja rumah berbanding lelaki yang bekerja. Begitu juga dengan pengurus wanita yang memainkan peranan penting dalam keluarga dan mempunyai masa kerja yang panjang, mereka mengalami konflik kerja-keluarga. (Stoner, et al., 1990/91). Maka mereka perlu bijak menggunakan masa dan tenaga mereka. Sekiranya peruntukan masa dalam keluarga lebih tinggi daripada kerja maka konflik di dalam domain kerja tidak dapat dikawal dan berlaku perlambakan konflik kerja dalam domain keluarga.

\section{Penglibatan Dalam Kerja dan Keluarga}

Penglibatan dalam kerja merupakan darjah penglibatan seseorang secara aktif dalam sesuatu tugas dan kepentingan kerja mencerminkan imej seseorang individu (Gorn \& Kanungo, 1980). Yogev dan Brett (1985) mendefinisikan penglibatan dalam keluarga sebagai darjah di mana seseorang mengenalpasti kepentingan peranan dalam keluarga terhadap imej dan konsep diri seseorang individu dan menunjukkan komitmennya terhadap peranan dalam keluarga.

Rabinowitz dan Hall (1977) mendapati kadar lantikhenti berkait secara negatif dengan penglibatan dalam kerja dan percaya bahawa pekerja yang tidak terlibat dalam kerja lebih cenderung untuk meninggalkan organisasi. Covin dan Brush (1993) mendapati penglibatan wanita dalam kerjanya terganggu apabila menjalankan tanggungjawab keibuan walaupun mereka berusaha sebaik mungkin seperti sebelum mempunyai anak.

Elloy dan Flynn (1991) menyatakan bahawa pasangan yang tidak mempunyai anak mempunyai darjah yang tinggi dalam penglibatan kerja dan komitmen terhadap organisasi berbanding pasangan yang mempunyai anak. Ini adalah akibat daripada keperluan penyesuaian yang tinggi oleh pasangan yang mempunyai anak berbanding pasangan yang tidak mempunyai anak. 
Kajian Stoner et al. (1990/91) mendapati apabila penglibatan dalam kerja lebih tinggi daripada penglibatan dalam keluarga maka berlaku peningkatan konflik kerja-keluarga. Dapatan Adams, King dan King (1996) menyokong kajian Stoner et al. dengan menunjukkan bahawa terdapat perkaitan yang positif di antara penglibatan dalam kerja dengan konflik kerja-keluarga.

Dapatan kajian Samihah (1998) dalam kalangan kumpulan profesional dan pengurusan di Kedah-Perlis melaporkan wanita yang berkahwin menunjukkan penglibatan dalam kerja dan penglibatan dalam keluarga yang tinggi. Penemuan beliau berbeza dengan dapatan Karambayya \& Reilly (1992) di mana wanita yang menunjukkan penglibatan yang tinggi dalam keluarga memperlihatkan penglibatan dalam kerja yang rendah.

\section{Hipotesis Kajian}

Kajian ini memfokus kepada hubungan di antara konflik kerja-keluarga dengan penglibatan dalam kerja dan penglibatan dalam keluarga. Konflik kerja-keluarga adalah pembolehubah bersandar. Pembolehubah bebas pula adalah penglibatan dalam kerja dan penglibatan dalam keluarga. Berdasarkan kerangka teoritikal, beberapa hipotesis kajian telah dibentuk iaitu:

Hipotesis Pertama: Terdapat perbezaan dalam konflik kerja-keluarga di antara pensyarah lelaki dan pensyarah wanita. Hipotesis Kedua: Terdapat korelasi yang signifikan di antara konflik kerja-keluarga dengan penglibatan dalam kerja. Hipotesis Ketiga: Terdapat korelasi yang signifikan di antara konflik kerja-keluarga dengan penglibatan dalam keluarga. Hipotesis Keempat: Penglibatan dalam kerja dan penglibatan dalam keluarga mempengaruhi konflik kerja-keluarga.

\subsection{METODOLOGI KAJIAN}

Kajian ini dilakukan secara tinjauan keratan rentas dan menggunakan kaedah Persampelan Rawak Berstrata di mana populasi kajian adalah pensyarah-pensyarah yang telah berkahwin dan mempunyai anak. Sampel kajian adalah seramai 201 orang responden.

Pengumpulan data dibuat menggunakan soal-selidik yang menggunakan skala Likert berbentuk 5 nilaian iaitu dari 1 (sangat tidak setuju) kepada 5 (sangat setuju). Soalan adalah berkisar tentang latarbelakang responden, konflik kerja-keluarga, penglibatan dalam kerja dan penglibatan dalam keluarga.

Konflik kerja-keluarga mengandungi 23 soalan yang berkisar tentang pengalaman responden dalam menjalani dua peranan iaitu peranan kerja dan peranan keluarga dan bagaimana reaksi keluarga dan responden terhadap permasalahan yang timbul. Skala ukuran ini diadaptasi daripada skala Kopelman et al. (1983), Conone et al. (1993), Thomas \& Ganster (1995) dan Simonetti et al. (1998). Soalansoalan yang diajukan adalah seperti "Kerja saya menghalang saya menghadiri majlis di sekolah anak saya", "Saya rasa bersalah meninggalkan anak saya dalam jagaan orang lain semasa dia sakit", "Saya rasa bersalah jika pasangan saya membuat kebanyakan kerjakerja di rumah" dan sebagainya.

Terdapat tujuh item yang mengukur penglibatan dalam kerja yang diadaptasi daripada skala Saleh \& Hosek (1976). Soalannya adalah berkisar tentang "kepuasan utama dalam diri yang datang dari kerja saya", "selalu datang kerja awal untuk membuat persediaan" dan sebagainya.

Penglibatan dalam keluarga diukur oleh empat soalan seperti kepentingan keluarga dan persepsi responden tentang sesuatu yang penting dalam diri mereka yang melibatkan keluarga mereka. Skala tersebut diadaptasi daripada Saleh \& Hosek (1976) dan Yogev \& Brett (1995).

Soal-selidik diedarkan oleh penyelidik kepada seorang pegawai di bahagian sumber manusia untuk diedarkan kepada responden terpilih. Kadar pulangan soal-selidik ialah 151 iaitu 75 peratus.

Data telah dianalisis menggunakan program SPSS. Analisis statistik seperti korelasi Pearson, statistik deskriptif, ujian-t dan regresi telah dilakukan ke atas data yang diperolehi.

\subsection{HASIL KAJIAN}

\section{Ciri Responden}

Statistik deskriptif menunjukkan responden lelaki adalah seramai 97 orang (64.2 peratus) manakala responden perempuan pula adalah 54 orang iaitu 35.8 peratus. 41.3 peratus responden memiliki anak dalam kategori umur di bawah 6 tahun; 37.1 peratus dalam kategori 6 - 12 tahun manakala bakinya (21.6 peratus) dalam kategori 13 tahun dan ke atas. Didapati seramai 27 responden (17.9\%) mempunyai pembantu rumah manakala 82.1 peratus (124 orang) tidak mempunyai pembantu rumah. Kebanyakan pembantu rumah responden melakukan semua kerja seperti menjaga anak, mengemas rumah dan memasak dan hanya sebilangan kecil pembantu rumah melakukan kerja-kerja tertentu sahaja. Bagi responden yang tidak mempunyai pembantu rumah, anak-anak mereka dihantar ke Taman Asuhan Kanak-kanak (TASKA), Tadika, rumah ibu mertua atau saudara-mara dan rumah jiran.

\section{Hubungan Di Antara Konflik Kerja-Keluarga Dengan Penglibatan Dalam Kerja Dan Penglibatan Dalam Keluarga}

Analisis korelasi dalam Jadual 1 menunjukkan tiada hubungan yang signifikan di antara konflik kerja-keluarga dengan penglibatan dalam kerja di mana $\mathrm{p}>0.05$. Hubungan yang wujud di antara kedua-dua pembolehubah tersebut hanyalah 4.7 peratus sahaja dan hubungan yang wujud tidak kuat. Bagi analisis korelasi di antara pembolehubah konflik kerja-keluarga dengan penglibatan dalam keluarga, didapati $\mathrm{p}>$ 0.05 dan $r=0.119$. Kesimpulan yang boleh dibuat bagi kedua-dua hipotesis adalah tiada hubungan di antara pembolehubah konflik kerjakeluarga dengan penglibatan dalam kerja dan penglibatan dalam keluarga. 
Jadual 1 Korelasi penglibatan dalam kerja dan penglibatan dalam keluarga dengan konflik kerja-keluarga

\begin{tabular}{|l|c|c|}
\hline & Penglibatan dalam kerja & Penglibatan dalam keluarga \\
\hline Konflik kerja-keluarga & 0.047 & 0.119 \\
\hline
\end{tabular}

\section{Perbezaan Konflik Kerja-Keluarga Di Kalangan Pensyarah Lelaki Dan Wanita}

Jadual 2 menunjukkan ujian-t ke atas pembolehubah konflik kerja-keluarga di kalangan pensyarah lelaki dan wanita. Berdasarkan ujian tersebut, keputusan yang didapati adalah $\mathrm{p}=0.690$ di mana $\mathrm{p}>0.05$. Maka $\mathrm{H}_{0}$ diterima. Dapatan menunjukkan bahawa tiada perbezaan yang signifikan di antara pensyarah lelaki dan wanita dalam konflik kerja-keluarga. Ini boleh dilihat pada nilai min pensyarah lelaki (3.27) dan wanita (3.23) di mana nilai min tersebut adalah hampir sama.

Jadual 2 Ujian-t - perbezaan konflik kerja-keluarga

\begin{tabular}{|c|c|c|c|c|}
\hline Pembolehubah & Jantina & Mean & $\begin{array}{c}\text { Signifikan } \\
\text { (2-tailed) }\end{array}$ & t \\
\hline \multirow{2}{*}{ Konflik kerja-keluarga } & Lelaki & 3.2737 & \multirow{2}{*}{0.690} & 0.399 \\
\cline { 2 - 3 } & Perempuan & 3.2343 & 0.69 \\
\hline
\end{tabular}

\section{Pengaruh Penglibatan Dalam Kerja Dan Penglibatan Dalam Keluarga Terhadap Konflik Kerja-Keluarga}

Analisis regresi telah diuji untuk menentukan sama ada penglibatan dalam kerja dan penglibatan dalam keluarga mempengaruhi konflik kerja-keluarga atau tidak. Jadual 4 menunjukkan kedua-dua pembolehubah bebas menerangkan sebanyak $1.4 \%$ perubahan dalam konflik kerja-keluarga, di mana ianya tidak signifikan seperti ditunjukkan pada nilai-F. Nilai $\mathrm{p}=0.347$, di mana $\mathrm{p}>0.05$. Maka hipotesis nul diterima. Dengan ini, faktor penglibatan dalam kerja $(p=0.876)$ dan penglibatan dalam keluarga $(p=0.182)$ tidak dapat menerangkan varian konflik kerja-keluarga secara signifikan. Sebagai kesimpulan dapatlah dikatakan bahawa penglibatan dalam kerja dan penglibatan dalam keluarga tidak mempengaruhi varian konflik kerja-keluarga.

Jadual 3 Pengaruh penglibatan dalam kerja dan penglibatan dalam keluarga terhadap konflik kerja-keluarga

\begin{tabular}{|c|c|c|c|c|c|c|}
\hline Pembolehubah & R Square & $\mathbf{F}$ & Sig. & B & Beta & $\begin{array}{c}\text { Coefficients } \\
\text { Sig. }\end{array}$ \\
\hline Konflik kerja-keluarga & \multirow{3}{*}{0.014} & \multirow{3}{*}{1.067} & \multirow{3}{*}{0.347} & & & \\
\hline Penglibatan dalam kerja & & & & $1.439 \mathrm{E}-02$ & 0.013 & 0.876 \\
\hline Penglibatan dalam keluarga & & & & 0.130 & 0.115 & 0.182 \\
\hline
\end{tabular}

Pembolehubah bersandar : Konflik kerja-keluarga

Pembolehubah bebas: Penglibatan dalam kerja, Penglibatan dalam keluarga

\subsection{PERBINCANGAN DAN KESIMPULAN}

Secara keseluruhannya, dapatan kajian ini tidak begitu memberangsangkan kerana gagal menolak hipotesis nul dan tidak mempunyai persamaan dengan kajian sarjana Barat. Ini boleh dilihat daripada hubungan di antara pembolehubah konflik kerja-keluarga dengan penglibatan dalam kerja. Hubungan yang wujud di antara kedua pembolehubah tersebut tidak kuat. Dapatan ini adalah bertentangan dengan Adams, King dan King (1996) yang mendapati bahawa hubungan yang signifikan wujud di antara penglibatan dalam kerja dengan konflik kerja-keluarga. Stoner et al. (1990/91) juga mendapati konflik kerja-keluarga menjadi bertambah teruk apabila permintaan kerja meningkat. Dapatan kajian ini bertentangan dengan kajian sarjana Barat kerana responden kajian ini merupakan pensyarah dan suasana kerja mereka lebih fleksibel berbanding kajian penyelidik lain yang memfokus kepada pihak pengurusan.

Dalam konteks hubungan di antara konflik-kerja keluarga dan penglibatan dalam keluarga, didapati tiada hubungan di antara kedua pembolehubah tersebut dan hubungan keduanya tidak kuat. Ini mungkin berlaku kerana ahli keluarga di rumah serta pasangan masingmasing turut membantu membereskan kerja-kerja rumah. Stoner et al. (1990/91) mendapati walaupun peningkatan permintaan dari keluarga adalah satu bebanan tetapi tiada hubungan yang wujud di antara konflik kerja-keluarga dengan penglibatan dalam keluarga kerana ia konsisten dengan jangkaan peranan tradisi wanita di mana peningkatan permintaan dalam domain keluarga lebih mudah diterima. Justeru, dapatan Stoner et al. (1990/91) mempunyai persamaan dengan hasil kajian ini.

Penerimaan konflik-kerja keluarga di kalangan lelaki dan wanita juga tidak menunjukkan banyak perbezaan ketara. Walaupun para pensyarah perlu memainkan pelbagai peranan semasa di tempat kerja tetapi mereka hanya bekerja selama lima hari dalam seminggu dan juga cuti semester yang panjang pada setiap tahun membolehkan mereka memberi tumpuan kepada peranan kelaurga. Dapatan kajian ini adalah songsang dengan dapatan Covin dan Brush (1993) di mana wanita lebih tinggi dipengaruhi konflik kerja-keluarga berbanding lelaki kerana wanita melihat isu ini lebih kritikal daripada lelaki. Justifikasi pernyataan yang songsang ini adalah penjagaan anak-anak mudah didapati menyebabkan peranan keluarga kurang berkonflik dengan peranan kerja.

Aspek lain yang dilihat dalam kajian ini adalah dalam kerja dan penglibatan dalam keluarga terhadap konflik kerja-keluarga.Didapati pembolehubah bebas iaitu penglibatan dalam kerja dan penglibatan dalam keluarga tidak mempengaruhi konflik kerja-keluarga. Dapatan 
Parasuranam et al. (1992) adalah songsang dengan penemuan kajian ini di mana ketegangan peranan dalam keluarga mengganggu peranan kerja dan menghasilkan penurunan dalam kepuasan kerja sama ada secara langsung atau tidak langsung dan ini akan mengurangkan penglibatan dalam kerja. Dalam satu kajian tentang profesional di sektor penjagaan kesihatan, Wright \& Noe (1996) mendapati bahawa apabila organisasi membantu pekerja mengatasi konflik kerja-keluarga menerusi alternatif seperti penjadualan yang fleksibel dan sokongan daripada pengurus maka kesan negatif seperti ketidakpuasan kerja menurun. Kesemua dapatan daripada kajian Barat tidak selari dengan penemuan kajian ini kerana responden dalam kajian ini tidak mengalami perlimpahan peranan yang teruk dalam domain kerja dan domain keluarga kerana terdapat kemudahan pembantu atau pusat penjagaan kanak-kanak (TASKA).

Sumber manusia merupakan aset penting yang berharga kepada sesebuah organisasi. Tanpa sumber manusia kewujudan sesebuah organisasi boleh dinafikan. Oleh itu, majikan perlu prihatin dan komited terhadap isu gunatenaga pada era millenium terutamanya isu tentang dwi-kerjaya. Permasalahan ini perlu diambil kira dalam penggubalan polisi organisasi (Sullivan \& Lussier, 1995) agar kadar lantikhenti dan ketidakhadiran di kalangan pekerja dapat dikurangkan (Covin \& Brush, 1993).

Pasangan dwi-kerjaya juga perlu mengimbangi peranan kerja dan keluarga yang perlu dimainkan agar mereka tidak terdedah dan dipengaruhi oleh konflik kerja-keluarga akibat daripada perlimpahan peranan dalam domain kerja dan juga domain keluarga (Zedeck \& Mosier, 1990). Penggabungan aspek individu dan majikan dapat mewujudkan gunatenaga cemerlang yang tidak merasa tertekan semasa melakukan peranan kerja dan keluarga sekaligus.

Berdasarkan penemuan dan perbincangan kajian ini, maka jelas didapati bahawa konflik kerja-keluarga tidak mempengaruhi peranan dalam kerja dan peranan dalam keluarga yang perlu dilaksanakan oleh para pensyarah kerana fleksibiliti tugas mereka. Ujian-t yang dilakukan cuba melihat secara terperinci perbezaan konflik kerja-keluarga yang dihadapi oleh pensyarah lelaki dan perempuan dan didapati tiada perbezaan yang signifikan. Analisis regresi juga menunjukkan pembolehubah bebas iaitu penglibatan dalam kerja dan penglibatan dalam keluarga tidak dapat menerangkan perubahan dalam konflik kerja-keluarga.

Memandangkan kajian ini hanya memfokus kepada interaksi dan hubungan di antara konflik kerja-keluarga dengan dwi-peranan yang perlu dimainkan oleh pasangan dwi-kerjaya maka wajarlah penyelidik lain terus berusaha menjalankan kajian dalam arena ini kerana kehadiran pasangan dwi-kerjaya dalam tenaga kerja semakin meningkat. Bidang yang boleh diterokai adalah pengubalan semula polisi sumber manusia organisasi ke arah penyesuaian terhadap tenaga kerja yang berdiversiti. Instrumen yang digunakan perlu dipelbagaikan kepada beberapa kaedah kutipan data untuk mendapat keputusan yang lebih tepat tentang konflik kerja-keluarga. Justifikasinya adalah kajian konflik kerja-keluarga berurusan dengan peristiwa subjektif dan kerap berurusan dengan penyebab yang terakhir.

\section{References}

Adams, G.A., King, L. A. \& King, D. W. (1996). Relationships Of Job And Family Involvement, Family Social Support And Work-Family Conflict With Job And Life Satisfaction. Journal of Applied Psychology, 81 (4), 411 - 420.

Bacharach, S. B., Bamberger, P. \& Conley, S. (1991). Work-Home Conflict Among Nurses And Engineers: Mediating The Impact Of Role Stress On Burnout And Satisfaction At Work. Journal of Organizational Behavior, 12, 39- 53.

Conone, R. M., Spiegel, M., Beckham, C. \& Miller, A. (1993). Balancing Work And Family: A Cooperative Extension Service Evaluation. Journal of Home Economics, $37-43$.

Covin, T. J. \& Brush, C. C. (1993). A Comparison Of Student And Human Resource Professional Attitudes Toward Work And Family Issues. Group and Organizational Management, 18 (1), $29-49$.

Duxbury, L. E. \& Higgins, C. A. (1991). Gender Differences In Work-Family Conflict. Journal of Applied Psychology, 76 (1), 60 - 74

Elloy, D. F. \& Flynn, W. R. (1991). Work vs Family: A Multiple Site Study Of Job Involvement Among Dual Wage Earner And Single Wage Earner Families. Proceedings of Pan-Pacific Conference VIII, Kuala Lumpur, Malaysia : A Business Economic \& Technological Exchange.

Frone, M. R. \& Rice, R. W. (1987). Work-Family Conflict : The Effect Of Job And Family Involvement. Journal of Occupational Behavior, 8 (1), 45 - 53.

Good, L. K., Gentry, J. W. \& Sisler, G. F. (1990). Work-Family Conflict And Retail Managers' Job Attitudes. Home Economics Research Journal, 18 (4), 323 - 335.

Gorn, G. J. \& Kanungo, R. N. (1980). Job Involvement And Motivation: Are Intrinsically Motivated Managers More Job Involved? Organizational Behavior \& Human Performance, 26, 265-77.

Greenhaus, J. H. \& Beutell, N. J. (1985). Sources of Conflict Between Work And Family Roles. Academy of Management Review, 10 (1), 76 - 88

Gutek, B. A., Searle, S. \& Klepa, L. (1991). Rational Versus Gender Role Explanations For Work-Family Conflict. Journal of Applied Psychology, 76 (4), 560 - 568.

Higgins, C., Duxbury, L. \& Lee, C. (1994). Impact of Life-Cycle Stage And Gender On The Ability To Balance Work And Family Responsibilities. Family Relations, $43,144-150$

Karambayya, R. \& Reilly, A. H. (1992). Dual Earner Couples: Attitudes And Actions In Restructuring Work For Family. Journal of Organizational Behavior, 13,585 $-601$

Kopelman, R. E., Greenhaus, J. H. \& Connolly, T. F. (1983). A Model Of Work, Family And Interrole Conflict: A Construct Validation Study. Organizational Behavior and Human Performance, 32, $198-215$.

Macewen, K. E. \& Barling, J. (1988). Interrole Conflict, Family Support And Marital Adjustment Of Employed Mothers: A short term, longitudinal study. Journal of Organizational Behavior, 9 (3), $241-250$.

Parasuraman, S. , Greenhaus, J. H. \& Granrose, C. S. (1992). Role Stressors, Social Support And Well-Being Among Two-Career Couples. Journal of Organizational Behavior, 13 (4), $339-356$.

Rabinowitz, S. \& Hall, D. T. (1977). Organizational Research On Job Involvement. Psychological Bulletin, 84 (2), 265 - 288.

Saleh, S. D., \& Hosek, J. (1976). Job Involvement: Concepts And Measurements. Academy of Management Journal, 19 (2), 213 - 224.

Samihah Khalil (1998). Pasangan Dwi-Kerjaya: Penstrukturan Semula Kerja Untuk Keluarga Di Kalangan Kumpulan Profesional Dan Pengurusan. Penyelidikan Geran Sekolah Pembangunan Sosial (SPS), Universiti Utara Malaysia, 35

Schermerhorn, J. R. Jr., Hunt, J. G. , \& Osborn, R. N. (1991). Making Organizational Behavior: Communication \& Conflict (4 ${ }^{\text {th }}$ ed.). USA: John Wiley \& Sons, Inc. Simonetti, J. L., Nykodym, N. \& Goralske, J. M. (1998). Family Ties: A Guide For HR managers. Personnel, 37 - 41.

Stoner, C. R, Hartman, R. I., \& Arora, R. (1990/1991). Work/Family Conflict: A Study Of Women In Management. Journal of Applied Business Research, 7 (1), 67 74.

Sullivan, S. \& Lussier, R. (1995). Flexible Work Arrangements As A Management Tool. Supervision, 56 (8), $14-17$.

Wright, P. M. \& Noe, R. A. (1996). Management Of Organizations: Conflict And Stress. USA: Richard D. Irwin, 690.

Yogev, S. \& Brett, J. (1985). Patterns of Work And Family Involvement Among Single And Dual-Earner Couples. Journal of Applied Psychology, 70 (4), 754 - 768.

Zedeck, S. \& Mosier, K. L. (1990). Work In The Family And Employing Organization. American Psychologist, 45 (2), 240 - 251. 